\title{
Failure of the Biguanides to Improve the Control of Unstable Diabetes Treated with Insulin
}

\author{
J. PiraRT \\ Allgemine Belgische Diabitesbond, Brussels, Belgium \\ Received: February 15, 1971, accepted: May 28, 1971
}

\begin{abstract}
Summary. 25 insulin-dependent diabetics had marked instability despite optimal treatment. These highly cooperative patients alternately received a placebo and the biguanide. They were aware that they were being treated with a new drug in the hope of reducing their instability. Long before this trial they were trained to record in a booklet their four daily urine tests (Clinitest + Acetest) and their hypoglycaemic reactions (occurrence, timing, causes if any) and to adjust their daily dose of insulin(s) to the results of the preceding days. They were seen about once or twice a month, carefully questioned and their booklets were examined and discussed. - A slight insulinsparing' effect was observed in one half of the cases. Some patients declared that the oral treatment improved their condition. However, the percentage of the urine tests and hypoglycaemic reactions recorded in their booklets, as well as the objective data gained on each visit, did not make it possible to differentiate between the degree of control obtained before and that obtained during or after the oral treatment, and between that obtained with a biguanide and that obtained with its placebo. It is concluded that the addition of biguanide to insulin is of no value in the treatment of unstable diabetes.
\end{abstract}

Echec d'un essai de stabilisation du diabète insulino dépendant par les biguanides

Résumé. L'effet "stabilisateur» des biguanides a été étudié chez 25 diabétiques traités à l'insuline et dont la glycómie était très instable malgré un traitement optimal. Ces patients ont reçu alternativement un biguanide et son placebo. Tous avaient un haut degré de coopération et d'éducation: ils étaient depuis longtemps habitués à noter les résultats de leurs 4 tests urinaires quotidiens (Clinitest, Acetest) ainsi que leurs malaises hypoglycémiques dans un carnet. Ils savaient ajuster correctement lours doses d'insuline(s) suivant les analyses des jours précédents. Leur degré de contrôle était coté après examen et dis. cussion de leur carnet et d'après les analyses faites à la consultation. - Certains patients furent convaineus de l'efficacité du traitement oral mais l'examen des données objectives obtenues à la clinique et l'examen de leur propre journal contredisait leurs affirmations. Les biguanides ont eu un petit effet d'épargne sur les besoins en insuline mais n'ont pu atténuer l'ampleur ni la fréquence des fluctuations glycémiques. Aucune différence appréciable n'a permis de croire à un effet pharmacologique ou à un effet placebo des biguanides dans le sens d'une stabilisation du diabète.

Das Versagen der Biguanide, die Kontrolle eines unstabilen, insulinbedürfigen Diabetes zu verbessern

Zusammenfassung. An 25 insulinbedürftigen Diabetikern, deren Blutzuckerwerte trotz einer optimalen Behandlung sehr instabil waren, wurde der Stabilisierungs. effekt der Biguanide untersucht. Diese Patienten haben wechselweise ein Biguanid oder sein Placebo erhalten. Alle waren sehr führungswillig und kooperativ: Sie waren seit langer Zeit daran gewöhnt, die Ergebnisse ihrer 4 Urinuntersuchungen (Clinitest, Acetest) und ihre Нypoglykämiebeschwerden in ein Heft einzutragen. Sie konnten ihre Insulindosen entsprechend den Befunden der Vortage gut anpassen. Der Grad ihrer Kontrolle wurde nach Durchsicht und Diskussion des Heftes und an Hand der bei der Konsultation durchgeführten Analysen eingeschätzt. - Einige Patienten waren von der Wirksamkeit der oralen Behandlung überzeugt, aber die objektiven Befunde in der Klinik und ihre eigenen täglichen Aufzeichnungen widersprachen diesen Behauptungen. Die Biguanide haben einen kleinen einsparenden Effekt auf den Insulinverbrauch, aber sie konnten nicht die Höhe und die Frequenz der Blutzuckerschwankungen vermindern. Es gab keinen bedeutsamen Unterschied, der einen pharmakologischen Effekt oder einen Plazeboeffekt der Biguanide auf die Stabilisierung des Diabetes glaubhaft machen konnte.

Key-words: Unstable diabetes, biguanides, degree of control.
Biguanides have been claimed to improve the degree of control of insulin-treated diabetics, not only in reducing their insulin requirements but also in flattening the wide and unexpected fluctuations of the blood sugar so typical of what has been called "brittle diabetes" $[1-6,8,9,11-14]$. This opinion has nearly always been based on clinical impressions since all studies except one [3] do not mention the use of suitable control patients or of control periods. Three studies using placebos were conducted by French and Scottish diabetologists on large groups of children. They concluded that both metformin and phenformin had a definite insuline-sparing effect but were unable to decrease the glycaemic instability $[7,10,15]$.

Systematic trials are difficult to perform because they unavoidably face three main difficulties:

1. Whereas "true" instability is very unfrequent in adults, cases with apparent instability (resulting from errors in the treatment) are common but are not suitable for such a study. The convenient cases are not easy to find.

2. The prescription of an oral drug with the hope of "smoothing" a "brittle diabetes" is necessarily accompanied by increased efforts and attention of both 
the doctor and the patient. This emphasizes the need for comparisons with a placebo.

3. The evaluation of the degree of control of an ambulant case of diabetes in the course of prolonged trials is very subjective.

This study is an attempt to overcome these drawbacks.

\section{Subjects}

In a series of about 800 insulin-dependent, lean diabetics, 25 adults were selected in an 8 year period because they all fulfilled the following requirements:

- they were totally insulin-dependent;

- they were treated by myself for many months;

- they were intelligent, highly cooperative and reliable;

- they were permanently affected with "brittle" diabetes despite optimal treatment;

- they had been accustomed for a long time to record in a booklet the tabulated results $( \pm 12 \mathrm{~A} . \mathrm{M}$., \pm 5 P.M., \pm 10 P.M., \pm 7 A.M. the next day) of their four daily urine tests (Clinitest-Acetest) and the occurrence of their hypoglycaemic reactions, as well as the possible causes of the most remarkable fluctuations in their diabetes;

- they had long since been instructed to adapt, by steps of four units, if needed, their doses of insulin every 3 to 6 days according to the results of the preceding days (a judgement based on the overall situation of a whole week), and they were used to doing this correctly;

- they lived in the near vicinity of the clinic and had the opportunity to come frequently;

- they tolerated the biguanides without too much gastric or intestinal discomfort;

- they were concerned with their glycaemic instability, but were free from neurotic tendencies;

- they were unaffected by other diseases that could influence their diabetic state.

The composition of the group studied is given in table 1 .

Table 1. Composition of the group studied

25 lean insulin-dependent unstable diabetics: $16 \mathrm{~F}, 9 \mathrm{M}$. Ages: 15 to 67 years $(\mathrm{m} .42 \mathrm{y})$.

Duration of diabetes: 1 to 23 years $(\mathrm{m} .9 .3 \mathrm{y})$. number of eases of more than 5 y duration : 17

Doses of Insulin: 25 to $80 \mathrm{u} . / \mathrm{d}$.

$$
\begin{array}{lccc}
\text { doses } & 25-39 & 40-59 & 60-80 \\
\text { cases } & 8 & 12 & 5
\end{array}
$$

Ketosis: rare in 18 cases, frequent in 7 cases (opinion based on periods of normal state, thus excluding acute diseases, stresses, failures of treatment, ...)

\section{Methods}

The same insulins were used throughout the trials.

The patients were informed that new drug's were being tried with the aim of "smoothing" the fluctuations of their blood sugar, but that they had to maintain the usual management of their diabetes (increase and decrease in insulin dosage as indicated by the urine tests, and according to the expected physical activities of every day). They were requested to reduce the dosage of the oral medication, if needed, in case of digestive disturbances, and to note in their diary all such changes and events. They followed a non-weighed diet comprising normal amounts of carbohydrates divided into three main meals and three small snacks all taken at set hours, which were approximately as follows: $7 A . M ., 10$ A.M., $1 P . M ., 4$ P.M., $7 P$. $M ., 10$ P.M. Fruit was restricted to about $200 \mathrm{~g}$ per day $(2 \times 100 \mathrm{~g})$, and sweets were forbidden except in small quantities, these having to be taken in periods of the day when the blood sugar was expected to be low ("blue periods with possible hypoglycaemic trends).

The biguanides to be studied were supplied by two manufacturers ${ }^{1}$ in special preparations together with indistinguishable placebos. They were metformin (trade name: Glucophage) in tablets of $500 \mathrm{mg}$ and phenformin (trade name:DBI) in the form of long-acting capsules of 50 mg. The trial with phenformin started on a double blind basis, but after a few weeks I was able to identify the digestive side effects reported by some patients. However, my diabetics never realized that they were participating in a trial with a placebo: the kinds of tablets or the two kinds of capsules were offered to them as "preparations with different speeds of absorption, one of which being not so well tolerated by the stomach or the bowel". Confidence was never lacking right up to the end of the study. Special attention was paid to avoid confusion or the mixing of the true and the false drugs. On each visit, the patient was requested to bring back his vial empty or not, and the bottle was soon replaced by the next one. The explanation for this change was a trial relating in the main to a comparison between one preparation and another, both probably being very useful in levelling out the blood sugar, but one of the two being likely to be better tolerated.

The patients were seen at intervals of about 2 or 3 weeks, usually in the afternoon: the booklet was examined and discussed, the declarations were noted on the medical chart, the urine passed when the visit was made and the blood sampled on this occasion. Both were analysed.

The patients were given, at random, one of the preparations as follows: ten patients received alternately phenformin or its placebo only; five patients received alternately metformin or its placebo only; ten other patients successively received both kinds of biguanides (alternating with their respective placebo) in periods separated by weeks or months without oral medication. Each type of biguanide (alternating with its placebo) was given for periods ranging from one month to one year as, shown in table 2.

\begin{tabular}{|c|c|c|c|c|c|}
\hline \multicolumn{6}{|c|}{ Number of patients in each class of duration } \\
\hline & 1 month & 2 months & 3 months & $\begin{array}{l}4 \text { to } 6 \\
\text { months }\end{array}$ & $\begin{array}{l}7 \text { to } 12 \\
\text { months }\end{array}$ \\
\hline phenformin & n 1 & 5 & 4 & 5 & 4 \\
\hline metformin & 5 & 3 & 2 & 5 & 1 \\
\hline
\end{tabular}

Table 2. Duration of the trials

Metformin was given in doses of 3 to 6 tablets of 500 $\mathrm{mg}$ a day and phenformin (long-acting) in doses of 2 to 3 capsules (of $50 \mathrm{mg}$ ) a day, according to the digestive tolerance of each subject.

1 I am indebted to U.S.V Pharmaceutical Corporation N.-Y. and Laboratoires Aron, who kindly provided me with large amounts of DBI and of Glucophage together with their respective placebos. 


\section{Results}

Ten patients complained of digestive intolerance. This side effect was usually mild, and its intensity was related to the dose of the compound. Abdominal discomfort occurred in 8 out of 20 series of trials with phenformin, in 4 out of 15 series of trials with metformin and in one trial with the placebo of phenformin. In no case had this side effect been discouraging enough to withdraw the drug or even to reduce its dosage for more than a few days.

Increase in the frequency of ketosis was not observed and the body weight did not change.

The use of the biguanides seemed to decrease the insulin requirements in 14 patients: this "sparing", effect amounted to 5 units/day in 9 patients, to 10 units/ day in 4 patients and to 15 units/day in one patient.

During the oral treatment (drug or placebo) the overall degree of control of the diabetes seemed practically unchanged. In fact, as judged by the declarations of the patients, the fluctuations of the blood sugar increased in 3 cases, decreased in 5 cases and were unchanged in the remainder. This opinion was not completely confirmed by the careful evaluation of the booklets of the patients (number of hypoglycaemic reactions reported, percentages of the bad, fair and good urine tests) nor by the urine and blood data obtained on the visit, since the instability was considered by myself to have increased in 3 cases but not to have consistantly decreased in any of them. During the time of the oral treatment, no difference could be found, either subjectively (patients' opinions) or objectively (patients' and doctor's written data), between periods with the biguanides and periods with its placebo.

In conclusion: 1 . there was no objective evidence of a pharmacological or of a placebo effect on the degree of control of the diabetes,

2. there was a slight insulin-sparing effect of the biguanide (not of its placebo) in about one half of the cases.

\section{Comments}

These highly coöperative patients made every effort to judge whether the tablets (or the capsules) were efficient in reducing the frequency and the intensity of their glycaemic fluctuations. In a final discussion five of them firmly believed that the new oral treatment was good.

However, a marked discrepancy was discovered between the patients' declarations and the patients' recorded observations. In general the appraisals of the diabetic were more favourable than the percentages of his own diary.

Some patients accepted the inconvenience of abdominal discomfort because they were convinced that the drug was useful. When shifted to the placebo (an "improved preparation with better intestinal absorption") they did not abandon their belief.

Some insisted on continuing indefinitely with the placebo even after having had long discussions when I tried to demonstrate clearly that their diabetic state was exactly the same as before the oral treatment. When the stocks of placebos were exhausted some insisted on having the drug prescribed and took it for months with my consent. They eventually abandoned the medication because their belief became progressively weaker (not for economic reasons since social security repaid $95 \%$ of the cost).

Finally in some of them the instability decreased months or years after completion of this trial. The reasons for this improvement remain obscure.

\section{Discussion}

My observations agree with those of Lestradet's $[7,10]$, on children whose dose of insulin was adjusted according to three daily urine tests. They are at variance with those of Bloom and Kolbe [3] who found a reduction in the variability of the weekly blood sugar readings during a 6 week treatment with phenformin compared with a 6 week treatment with a placebo. The present study differs from that of Bloom and Kolbe in three respects:

1. all my patients had unstable diabetes whereas those of Bloom had not been particularly selected for their instability.

2. all my patients had been accustomed for a long time to adjust their doses of insulin very accurately (they had been selected because they knew the rules of the "game" well). More than two thirds of Bloom's patients were unable to do so and, in the remainder, the degree of knowledge, skill and coöperation was not stated.

3. the overall degree of control of my patients was based on their four daily urine tests and their careful record of all hypoglycaemic reactions plus my own observations, questions and measurements of blood and urine sugar on each visit. On the contrary, the quoted study was, in the main, based on weekly determinations of urine and blood sugar. In unstable diabetes the speed of the glycaemic fluctuations is not a matter of days or weeks but rather of hours and days. What Bloom's study shows well is an insulinsparing effect of the biguanides, and this is in accordance with the general consensus as well as with my own data. No convincing evidence of a reduction in the circadian glycaemic fluctuations of unstable cases emerges from Bloom's data or from mine.

\section{Conclusions}

On the whole, the use of biguanides to stabilize "difficult" cases of diabetes was disappointing. Until it is established that these agents have a "smoothing" effect on the blood sugar, they should not be prescribed to insulin-dependent diabetics for the following reasons:

1. Their insulin sparing effect, though real, is trifling as long as the injections cannot be completely stopped. 
2. One patient in three complains of digestive discomfort with the usual doses of 2-4 tablets of metformin or 1-3 capsules of phenformin, and many more complain when given higher doses that might probably be more useful. Nausea or loss of appetite may disturb the diabetic balance.

3. Biguanides can at times be toxic: for instance the phenformin-induced lactic acidosis may add its own effect to that of diabetic acidosis.

4. These drugs are very expensive either to the patient or to the community.

5. Their use may be misunderstood by the patient (for instance "one capsule in the evening can replace my evening injection") and may divert the attention every diabetic ought to pay to his diet, to the dosage of his insulin and to many other duties.

\section{References}

1. Barclay, P.L.: Clinical evaluation of phenformin (DBI) in office practice. J. Amer. med. Ass. 174, 474$480(1960)$.

2. Berger, W., Constam, G.R., Siegenthaler, W.: Die Behandlungsmöglichkeiten des Diabetes Mollitus mit Biguaniden. Klinische Erfahrungen bei 122 Diabetikern mit Dimethylbiguanid (Glucophage). Schweiz. med. Wschr. 96, 1335 (1966).

3. Bloom, A., Kolbe, R.J.: Phenformin in insulin-dependent diabetics. Brit. med. J. 1970 I, $660-662$.

4. Creutzfeld, W., Soeling, H.D., Zarday, Z.: The combined use of insulin, tolbutamide and biguanides in the treatment of diabetes mellitus. Metabolism 12, 264 (1963).

5. Derot, M., Pignard, P., Rathery, M.: Les biguanides antidiabétiques. In Journées de Diabétologie de l'Hôtel-Dieu, p. 387. Paris: Edit. Flammarion 1969.
6. Fabrykant, M., Ashe, B.I.: Use of long-acting phenformin (DBI) with insulin in insulin-dependent diabetes. Methabolism 10, 684 (1961).

7. Gregoire, J., Quentin, C., Labram, C., Lestradet, H.: Résultats de l'association phenformine-insuline chez 50 jeunes diabétiques. Le Diabète (Le Raincy) suppl. 16, 96(1968).

8. Klein, W., Hole, P., Dietzmann, H.B.: Insulinresistenz, brittle Diabetes und Verhalten der Nüchtern Insulin Aktivität unter Biguaniden. Münch. med. Wschr. 111, 1908-1912 (1969).

9. Krall, L.P., Bradley, R.F.: Clinical evaluation of formamidyliminourea a new biguanide oral blood sugar lowering compound: comparison with other hypoglycemic agents. Ann. intern. Med. 50, 586 (1959).

10. Lestradet, H., Besse, J., Billaud, L. : Etude de l'action d'un biguanide (la NN diméthylguanylguanidine) sur un groupe de 235 enfants diabétiques. Presse Méd. 68, 391 (1960).

11. Leiser, A.E.: Long-acting DBI in treatment of unstable adult diabetics. Texas State J. Med. 59, 508 (1963).

12. Mehnert, H., Krall, L.P.: Möglichkeiten und Grenzen der Diabetestherapie mit Biguanidderivaten. Dtsch. med. Wschr. 85, $577(1960)$.

13. Messens, Y., Margoulies, M.: Traitement de 81 cas de diabète sucré par le NN diméthylbiguanide. Rev. Méd. Liège 20, 607 (1965).

14. Walker, R.S., Linton, A.I. : Observations on the treatment of young diabetics with an oral drug (phenethylbiguanide). Acta endocr. (Kbh) 32, 491 (1959).

15. Fergusson, A. W., De la Harpe, P. L., Farquhar, J.W.: Dimethylbiguanide in the treatment of diabetic children. Lancet 1961 I, 1367.

Dr. J. Pirart

234 B, Avenue Churchill

1180 Bruxelles

Belgique 